\title{
The Mediation Effects of Purchasing Strategy and Supplier Integration on the Relations Between Purchasing Skills and Corporate Performance
}

\author{
Isabel Franklin de Jesus Marques Belo ${ }^{1}$, Alvaro Menezes Amaral ${ }^{2}$, Teresa Belo ${ }^{3}$, \\ Master of Business Administration (MBA) Program, Dili Institute of Technology (DIT), Timor-Leste \\ Email: isabelfranklinbelo@yahoo.com,alvaromenezesamaral@gmail.com,teresafreitas.belo@hotmail.com
}

\begin{abstract}
The objectives of this study are to: 1) test the influence of purchasing skills on corporate performance; 2) test mediation effect of strategic purchasing on the relationship between purchasing skills and corporate performance; and 3) test the mediation effect of supplier integration on the relationship between purchasing skills and corporate performance. This research carried out in 105 restaurants as micro and small enterprises (MSEs) in Dili, and questionnaires were used to collect data. SMART-PLS 3.0 was used to test hypothesis. The findings revealed that purchasing skills had no significant impacts on corporate performance, while supplier integration fully mediated the relationship between purchasing strategy and corporate performance. By contrast, strategic purchasing has no significant impact on the relationship between purchasing skills and corporate performance. This research extends the empirical works of Carr and Smeltzser (2000), Carr and Pearson (2002) and Cho et al. (2019) by using a combined strategic purchasing and supplier integration as mediation variables to enhance the relations between purchasing skills and corporate performance. This study also contributes to the debate on firm's resources and capabilities and their impacts on competitive advantages and firm performance in emerging countries. The study practically contributes to the restaurant regulators and managers which aim to enhance corporate performance by using supplier integration and strategic purchasing.
\end{abstract}

Keywords: Purchasing skills, supplier integration, strategic purchasing, and corporate performance.

\section{Introduction}

The application of purchasing skills is an important activity which affects corporate performance. Corporates are required to diligently obtain products and services which will reinforce their capabilities to fulfill rapid customer demands (Carr and Pearson, 2002). Therefore, corporates will seek to develop strategic fitness to ensure purchasing skills will adequately support overall corporate activities, ultimately enhancing corporate competitive position and performance. This is particularly true in dealing with rapid changes of customer demands (Cho, Bonn, Giunipero ho Divers, 2019). Conversely, corporate performance is closely related to technical knowledge, interpersonal skills and managerial skills (Carr and Smeltzer, 2000; Cho et al., 2019; Schütz, 2019).

Purchasing skills contribute to developing effective and innovative strategies which help companies to ensure cost saving (Schütz, 2019) and achieve high returns. Effective and innovative purchasing strategies mean that companies have various effective purchasing methods to undertake purchasing activities to get high quality, speedy delivery, and cost savings (Carr and Pearson, 2002).

In order to undertake effective product and service provision, corporates can undertake innovative purchasing methods such as supplier integration (Fawcett et al., 2010), leading to enhanced corporate purchasing performance (Wei ho Lau, 2010; Schiele, 2010; Kleinschmidt, De Brentani and Salomo, 2007), as buyers and suppliers are strategic partners working together as the main driving forces for enhancing their industrial competitive position (Barney, 1991; Carr and Pearson, 2002).

A number of empirical studies confirm that supplier integration significantly positively effects corporate performance (Flynn, Huo and Zhao, 2010; Perols, 2013; Prajogo and Olhager, 2012; Feyissa, Sharma and Lai, 2019). Nevertheless, supplier integration can adversely influence the purchasing process, leading to reduced corporate profitability as a result of distance from buyers (Demeter, 2013). Heterogeneous results of empirical studies require continuous study to develop strategic fitness and contingency approaches to retain a competitive corporate position. A dynamic industry environment, company size, type, as well as geographical difference and technological advancement has different impacts on corporate performance, and so impact the efforts to develop such strategies.

This study aims to test the mediation effects of strategic purchasing and supplier integration on the relationship between purchasing skills and corporate performance. This can help restaurants which are mainly categorized as micro and small enterprises (MSEs) to develop appropriate strategies for sustaining their high competitive position and performance. The restaurants were chosen due to restaurants are facing significant growing numbers which contribute to generate incomes to the transition economic countries, and create significant job opportunities for local people. However, the increasing number of restaurants also leading to pushing the intense competitions which might threat industry competitiveness and sustainable financial 
performance. Restaurants need to develop strategic purchasing and supplier integration as restaurant's possible strategy to secure their competitive advantages and sustainable financial and non-financial performance. Unfortunately, there are limited and inconsistency empirical studies on purchasing skills, strategic purchasing, supplier integration and corporate performance in restaurant industry.

\section{Theoritical Frameworks}

\subsection{Purchasing skills}

Firms are required to obtain materials and services which will reinforce their ability to fulfill customer's demands (Carr and Pearson, 2002). Purchasing skills play an important role for a company to acquire goods and services. Purchasing skills are closely related to good knowledge of products, buyers, suppliers and markets. Multi-dimensional knowledge and skills such as technical knowledge, interpersonal, analytical and managerial skills in good purchasing are considered key capabilities to obtain quick, cheap, quality products and services (Cho et al., 2019). Therefore, purchasing skills enable firms to establish product and service supply strategies and management to enhance their overall company strategies (Carr and Pearson, 2002; Feisel, Hartmann and Schober, 2008) leading to enhancing firm competitive position and sustainable performance (Carr and Smeltzer, 2000).

According to the resource-based view (RBV), firms with great resources and capabilities will have good knowledge and skills to buy products and services, which ultimately leads them to achieve a strong, competitive position and performance compared to their rivals (Barney (1991). Firms can sustain their competitive positions, if they can precisely develop, retain and utilize their resources and capabilities such as with new equipment, new methods, technology, qualified human resources and well-established integrative suppliers to undertake purchasing functions and strategy (Carr and Smeltzer, 2000). However, with the recent high intensity of competitiveness, dramatic environment changes, and rapid technological innovation and progress, companies are required to establish collaborative networks between buying and supplying companies to share their resources in order to undertake efficient purchasing strategy and execution, to get mutual benefits, extend market share and retain sustainable performances (Lawson et al., 2009).

In line with resource-based theory, purchasing skills are considered as firm intangible resources which have great impacts on firm performance (Karttunen, 2018). Therefore, companies are required to develop distinctive resources and capabilities with high value, which are unique, inimitable, rare and well-organized to undertake purchasing goods and services, in order to sustain high competitive advantages and reach sustainable performances (Barney, 1991; Carr and Pearson, 2002).

\subsection{Supplier integration}

Supplier integration is part of the supply chain, through which firms build partnerships to work to offer goods and services based on customer demands through integrated structures, strategies, and collaborative practices and processes (Zhiqiang Wang et al., 2016; Yang et al., 2017). Supplier integration is a collaboration between purchasing companies and supplier companies in order to mutually exchange information, data, inventory plans, logistics, new product development, and specific product investment (Cho et al., 2019) based on openness and trust (Abrahamsen and Håkansson, 2015; Zhiqiang Wang et al., 2016).

Supplier integration helps to enhance the performance of purchasing companies as they can mutually share systems in order to get mutual benefits such as price reduction, inventory management, increased orders, quality control, customer satisfaction and profitability (Danese, 2013). This leads to efficient resource use, which improves capacity to offer high value products to customers (Lockström and Lei, 2013), targeted inventory planning and estimation, and minimizes uncertainty (Li et al., 2016). Therefore, supplier integration is a unique relationship between companies to gain new ideas, products and services with high value, which are inimitable and rare, and which are organized, as a source of competitive advantage (Barney, 1991; Zhiqiang Wang et al., 2016). Supplier integration combines internal resources and capabilities of the buying and supplying corporates to undertake joint activities to gain mutual benefits in their business processes (Wagner 2003; Monczka et al., 2016).

\subsection{Strategic Purchasing}

Organizational strategy is generally divided into strategic formulation, strategic implementation, and strategic evaluation (Ateş, van Raaij and Wynstra, 2018). Strategic purchasing is an integrated part of a company's plan to reach its objectives. Strategic purchasing is a good corporate strategy to effectively buy products and services with a focus on quality, timely delivery, and a minimized price in order to help the company reach its objectives (Carr and Pearson, 2002). Purchasing managers are required to know the purchasing objectives, which then lead them to develop purchasing strategies based on costs, quality, delivery, and flexibility (Ateş, van Raaij and Wynstra, 2018).

Strategic purchasing involves developing a formal purchasing plan, reviewing and adjusting the plan to ensure the corporate entity reaches its goals (Carr and Pearson, 2002). So, purchasing strategy is also seen as a cycle of activities from planning, implementing, controlling and evaluating strategic purchasing and the operation of the corporate entity, aiming to ensure it successfully meets its objectives (Feisel, Hartmann and Schober, 2008). To this, the corporate can build long-term partnerships to get contracts, with attention paid to competency, standards, and supply chain value change analysis and costs. This includes 
Vol.2, Issue.1, pp.1-13, 2020

Available online at: https://tljbm.org/jurnal/index.php/tljbm

considering supply consistency, the supplier's financial stability and financial position, cost capability, and techniques as foundational for decision making in order to secure the corporate's competitive position (Thrulogachantar and Zailani, 2011).

There are two types of strategic purchasing namely (1) tendering processes, which could help to obtain cheap, quality, quick and reliable product delivery; and (2) focusing company procurement from suppliers with whom the corporate has good partner relationships (Ahola et al., 2008). Yoon and Moon (2019) state that purchasing companies need to increase the number of supplying companies to simulate competition among them, which helps to obtain cheap and quality products (type 1). Type 2 is done through establishing long term mutual partnerships with a supplying company in order to reduce transaction costs, and enhance synergetic work via long term collaboration. Nonetheless, neither purchasing strategy has a great advantage over the other. It purely depends upon the company's contextual demand, resources and capabilities.

\subsection{Corporate Performance}

Corporate performance is a key parameter to measure its success in meeting its objectives, and test the effectiveness of their developed strategy. To reach organization objectives, corporates need to develop the best strategy (Salehzadeh $e t$ al., 2017). Therefore, investors and managers need to know corporate performance measurements in order to adjust corporate strategy to meet sustainable performance outcomes (Lee et al., 2015).

To achieve a better competitive position and sustainable performance, corporates continuously measure key financial parameters such as return on investment (ROI), return on assets (ROA), return on equity (ROE), and profitability. However, some authors also criticize the measurement of corporate performance only based on financial performance as this only covers a short-term basis, and is unable to respond to the strategic issue and performance (Kaplan and Norton, 1992; Hilman and Kaliappen, 2015). Therefore, Kaplan and Norton (1992) recommend an integrated corporate performance measurement such as learning and growth, internal process, customer satisfaction and finance into corporate performance measurement. Therefore, recent empirical studies have sought to incorporate financial and non-financial performance measures into corporate performance monitoring (Zhining Wang et al., 2016; AlSurmi et al., 2019; Saldanha et al., 2019; Seifzadeh and Rowe, 2019).

In this study, we used financial and nonfinancial performance to measure corporate performance. The financial performance was measured by using return on investment (ROI), total income growth, net profit growth (Saldanha et al., 2018; Cho et al., 2019), and return on assets (ROA), while nonfinancial performance was measured by sale growth, market share, and customer satisfaction (Saldanha et al., 2019).

\section{Hypothesis Development}

\subsection{Purchasing skills and Corporate Performance}

Knowledge of food purchasing process is a determinate factor contributing to firm performance. An organization which has adequate knowledge of good purchasing will obtain cheap, quality, and easily acquired goods in the short term. Nonetheless, the impact of good purchasing is not similarly felt across all firms. Firms with better resources and capabilities to invest in personnel professional development will have better purchasing performance, ultimately improving firm performance in a positively reinforcing cycle (Schütz et al., 2019). Numerous empirical studies reveal that purchasing skills have significant impacts on firm performance (Carr and Smeltzer, 2000; Cho et al., 2019). Therefore, procurement managers are required to have project execution skills and cost analysis in order to hold an holistic project view and control cost and time inputs, and therefore performance (Karttunen, 2018). Hence the following hypothesis was developed:

$\mathrm{H}_{1}$ : Purchasing skills positively and significantly influence corporate performance.

\subsection{Purchasing skills and Strategic Purchasing}

Purchasing skills influence on corporate purchasing strategy, ultimately driving corporate performance. Purchasing skills consist of technical knowledge, managerial skills and interpersonal skills which are valuable resources and capabilities for developing innovative, unique, valueadded purchasing strategies which lead to enhanced corporate competitive advantages. According to resourcebased view theory (RBV), corporates with better resources and capabilities will overcome their rivals in intense industrial competition (Barney, 1991). This view is confirmed by an empirical study of Cho, Bonn and Terrell (2019) which revealed that purchasing skills reflected by technical knowledge, managerial skills and interpersonal skills have significant effects on strategic purchasing. Henceforth, it is proposed that:

$\mathrm{H}_{2}$ : Purchasing skills positively and significantly influence on strategic purchasing.

\subsection{Purchasing skills and Supplier Integration}

Purchasing skills have three dimensions namely; technical knowledge, interpersonal skills and managerial skills. Firms that have these three skills will be able to develop better purchasing strategy. According to RBV, firms with better resources and capabilities will be able to develop 
unique, high-value, inimitable, organized products and services based on customer needs, leading to enhanced competitive position compared to their rivals (Barney, 1991). Corporate relationships, networking, connection and collaborative works, which offer opportunities for new products and services, are considered a firm's intangible resources. Therefore, profit and non-profit organizations seek to develop these intangible resources to sustain their competitive position and performance. Coordination and functional integration help to enhance purchasing performance, ultimately contributing to increasing corporate performance (Foerstl et al., 2013). Several empirical studies revealed that purchasing skills positively and significantly influence supplier integration (Danese, 2013; Abrahamsen and Håkansson, 2015; Cho et al., 2019). Therefore, this research proposes the following hypothesis:

$\mathrm{H}_{3}$ :Strategic purchasing positively and significantly influences supplier integration.

\subsection{Strategic Purchasing and Corporate Performance}

Today, strategic purchasing is an important activity for both profit and non-profit organizations. Strategic purchasing is focused on how companies can work together in order to obtain good quality, cheap and quick products, leading to mutual benefits (Lawson et al., 2009) and enhancing performance (Carr and Smeltzer, 2000). Companies with extensive working cooperation will be enabled to obtain external resources and capabilities, which contribute to enhanced performance compared to rivals (Barney, 1991). Several empirical studies confirm that strategic purchasing positively and significantly influences corporate performance (Carr and Pearson, 2002; Thrulogachantar and Zailani, 2011; Cho et al., 2019). Henceforth, it is proposed that:

$\mathrm{H}_{4} \quad$ :Strategic purchasing positively and significantly influences corporate performance.

\subsection{Supplier Integration and Corporate Performance}

Supplier integration has a significant impact on corporate performance. Therefore, companies try to establish strategic alliances in order to purchase and supply products in high concentrations (Fawcett et al., 2010). When suppliers are geographically far from buying companies, both companies will establish an easy and quick communication (Narasimhan and Das, 2001; Haartman et al., 2015) in order to obtain quick, and cheap product procurement and delivery (Kleinschmidt et al., 2007; Demeter, 2013). Flexible suppliers are able to easily adjust their purchasing supply chains and provide feedback to product design, process, and procedural quality in order to help purchasing performance which ultimately contributes to sustainable performance (Lawson et al., 2009). Numerous empirical studies show that supplier integration has a positive and significant impact on corporate financial performance (Lawson et al., 2009; Huo et al., 2013; Li et al., 2016; Huang and Huang, 2019). Therefore, we propose the following hypothesis:

$\mathrm{H}_{5}$ : Supplier integration has a positive and significant effect on corporate performance.

\subsection{Purchasing Skills, Strategic Purchasing and Corporate Performance}

Purchasing skills normally manifested by technical knowledge, managerial skills, interpersonal skills, and analytical skills have a positive impact on strategic purchasing (Carr and Pearson, 2002; Cho et al., 2019). A company which has good resources and capability will be able to develop good strategic purchasing which then leads to enhanced purchasing performance and corporate performance (Barney, 1991). These resources and capabilities are not necessarily available within the company, but can be accessed externally from partner organizations. These resources, namely human resources, enhance a corporate's competitive position and performance compared to its rivals (Barney, 1991; Jia et al., 2014). Various empirical studies show that strategic purchasing has a positive and significant impact on corporate performance (Carr and Smeltzer, 2000; Lawson et al., 2009; Ateş, van Raaij and Wynstra, 2018; Cho et al., 2019). Therefore, strategic purchasing can enhance corporate performance through the application of knowledge and skills. Buyer companies try to achieve purchasing performance in cost, quality, and timely product delivery through their networks and good relationships with other companies (Yoon and Moon, 2019). Hence we propose the following hypothesis:

$\mathrm{H}_{6}$ :Strategic purchasing plays a significant role in mediating the relationship between purchasing skills and corporate performance.

\subsection{Purchasing Skills, Supplier Integration and Corporate Performance}

Supplier integration has great impacts on corporate performance. Integrating their resources and capabilities helps corporates to enhance their competitive position and reach sustainable performance (Danese, 2013; He et al., 2014; Abrahamsen and Håkansson, 2015; Yang et al., 2017; Feyissa, Sharma and Lai, 2019). Therefore, supplier integration has significant roles to influence corporate financial performance (Lawson et al., 2009; Huo et al., 2013; Li et al., 2016; Huang and Huang, 2019).

$\mathrm{H}_{7}$ : Supplier integration has significant impact on the relationship between purchasing skills and corporate performance. 
Vol.2, Issue.1, pp.1-13, 2020

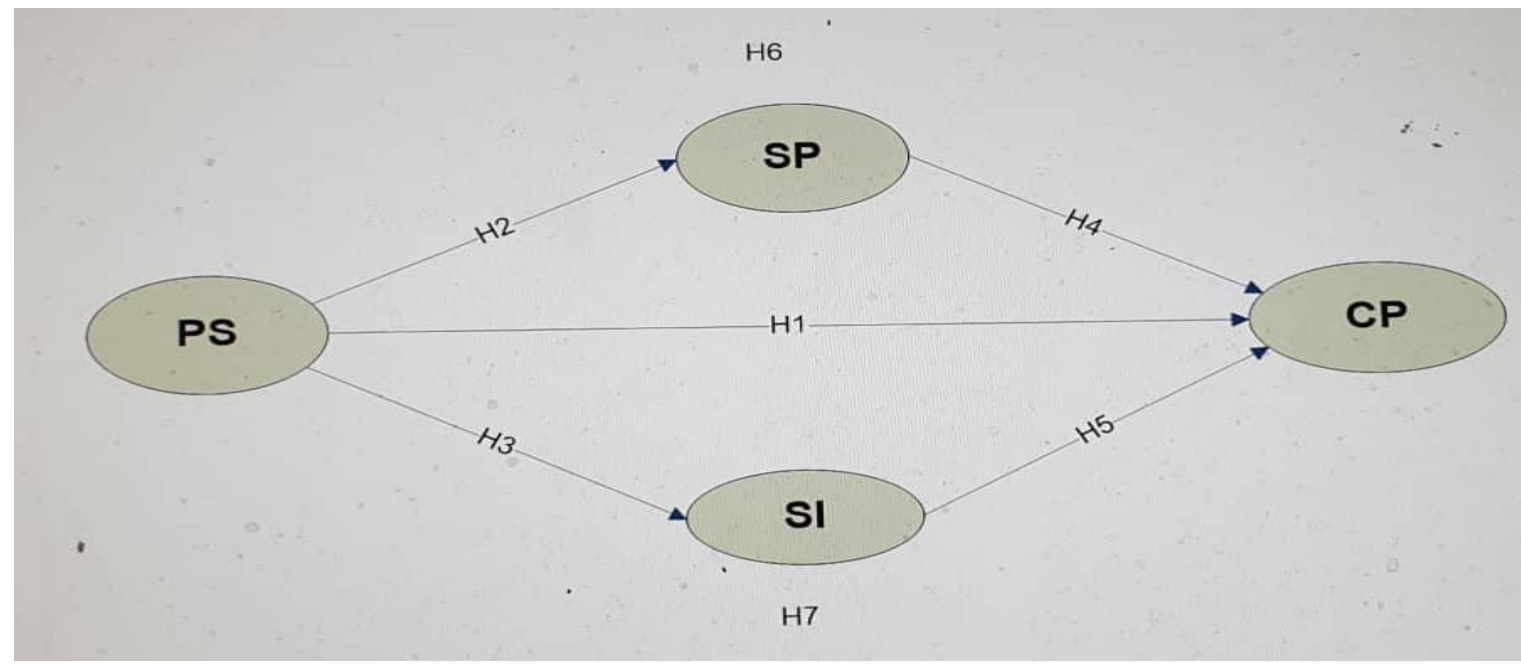

Figure 2.1. Research model

$(\mathrm{PS}=$ Purchasing skills, $\mathrm{SP}=$ Strategic purchasing, $\mathrm{SI}=$ Supplier integration, $\mathrm{CP}=$ Corporate

\section{Research Methods}

This research was carried out in 105 restaurants in Dili from October to December 2019. The sample size of 105 above the minimum required by the SMART-PLS 3.0 rule of thumb of ten times the largest number of inner model paths directed at a particular construct in the inner model (Hair et al., 2014; Andrei et al., 2017).

Five Scale Likert of survey questionnaire was used to collect the data. The survey instrument was developed from previous studies using a scale from 1 (strongly disagree) to 5 (strongly agree) for respondents. All items of purchasing skills adopted from Cho et al. (2019), purchasing strategy from Carr and Pearson (2002) and Cho et al. (2019). Corporate performance divided into financial and nonfinancial performance. The financial performance was measured by return on investment (ROI), total income growth, net profit growth (Saldanha et al., 2018; Cho et al., 2019), and return on assets (ROA), while nonfinancial performance was measured by sale growth, market share, and customer satisfaction.

SMART-PLS 3.0 was used to test reliability, validity and hypotheses. This statistical computer package is widely used for small sample sizes (of up to 30 participants), formative/reflective indicators, multi-variable analysis, data normality required, and collinearity testing (Hair et al., 2014; Saldanha et al., 2018, 2019). Cronbach's Alpha (CA) and composite reliability (CR) were used to test reliability (Hair et al., 2014; Saldanha et al., 2018). The convergent validity was tested using indicator loading or outer loading (OL) and average variance extracted (AVE) (Hair et al., 2017). Discriminant validity testing used Fornell-Larcker criterion (Hair et al., 2014) and heterotrait-monotrait (HTMT (Henseler et al., 2015). Hypothesis test was carried out by using path coefficient ( $\mathrm{T}$ and $\mathrm{P}$ values) observing direct and indirect effects from bootstrapping calculation (Hair et al., 2014; Hair et al., 2017; Saldanha et al., 2018).

\section{Research Methods}

\subsection{Reliability and Validity}

Outer models are measured using the following parameters: indicator reliability, internal consistency reliability, convergent validity, and discriminant validity (Abd Razak, Ab Rahman and Borhan, 2016). To test the reliability of the measurement model, composite reliability (CR) and Cronbach's Alpha (CA) values are used to ensure the reliability of the measurement model using Algorithm SMART-PLS 3.0. Table I shows that the CR and CA values of all items exceed the threshold point of 0.7 (Hair et al., 2017; Hair et al., 2018; Cepeda-Carrion et al., 2019), therefore, all items are reliable to be used in this model.

In general, there are two validity tests, namely convergent validity and discriminant validity. Convergent validity is measured by outer loading (OL) or indicator loading, and average variance extracted (AVE). AVE and OL values of all items should be above the threshold values of 0.5 and 0.7 respectively to demonstrate an acceptable degree of convergent validity (Hair et al., 2017). Figure 4.1 shows the OL values of all items exceed the threshold values of 0.7, and AVE values as shown in Table I exceed the threshold values of 0.5 . Therefore, all items are valid to use in this model based on convergent validity test. 
Vol.2, Issue.1, pp.1-13, 2020

Table I. Reliability and Validity using SMART-PLS 3.0

\begin{tabular}{cccc}
\hline Item & CA & CR & AVE \\
\hline CP1 & 0,858 & 0,903 & 0,700 \\
CP2 & 0,804 & 0,886 & 0,722 \\
IS & 0,872 & 0,908 & 0,665 \\
MS & 0,838 & 0,883 & 0,603 \\
SI & 0,883 & 0,915 & 0,686 \\
SP & 0,847 & 0,896 & 0,683 \\
TK & 0,917 & 0,938 & 0,752 \\
\hline
\end{tabular}

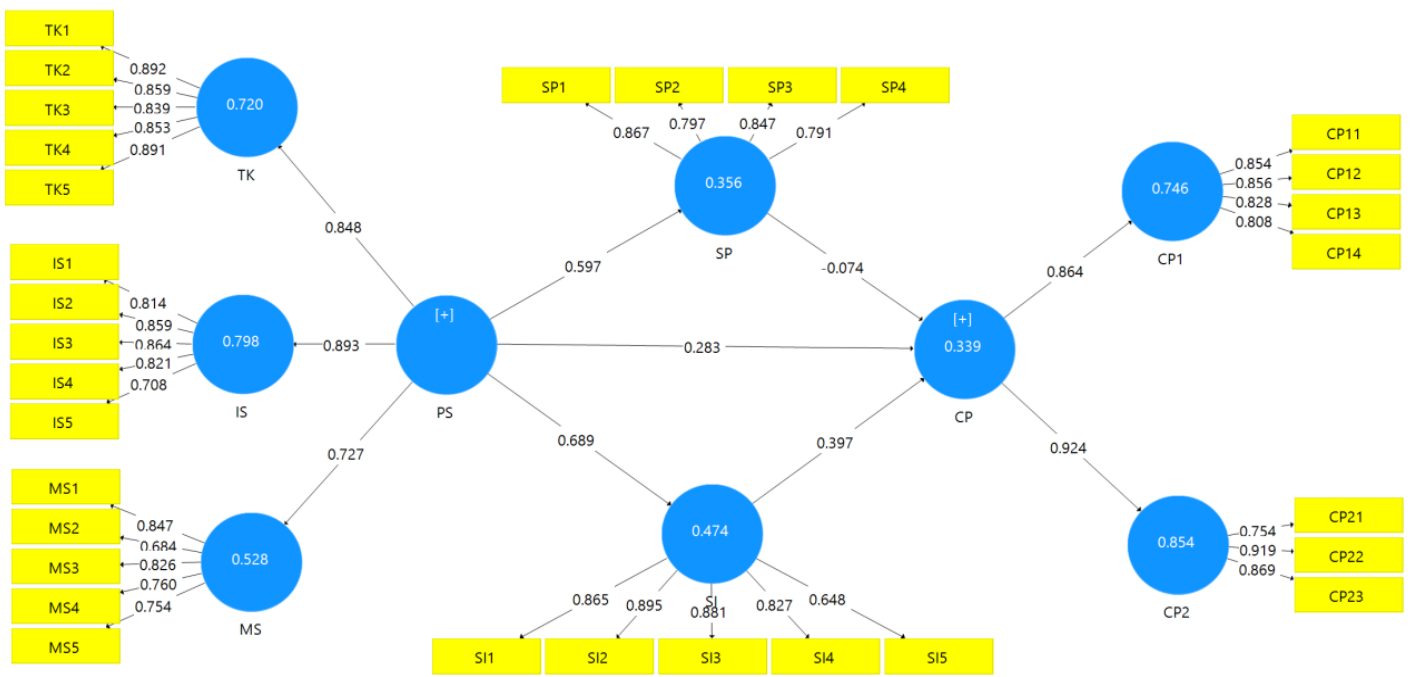

Figure 4.1. Outer loading for convergent validity derived from Algorithm SMART-PLS 3.0

To assess the discriminant validity between constructs, we used Fornell-Larcker criterion. This method states that the construct shares more variance with its indicators than with any other construct.

Table II. Discriminant validity Test based on Fornell-Larcker Criterion

\begin{tabular}{ccccccccc}
\hline & CP1 & CP2 & IS & MS & PS & SI & SP & TK \\
\hline CP1 & $\mathbf{0 , 8 3 7}$ & & & & & & & \\
CP2 & 0,622 & $\mathbf{0 , 8 5 0}$ & & & & & & \\
IS & 0,339 & 0,417 & $\mathbf{0 , 8 1 5}$ & & & & & \\
MS & 0,178 & 0,351 & 0,537 & $\mathbf{0 , 7 7 7}$ & & & & \\
PS & 0,340 & 0,510 & 0,893 & 0,727 & $\mathbf{0 . 7 0 0}$ & & & \\
SI & 0,368 & 0,547 & 0,659 & 0,366 & 0,689 & $\mathbf{0 , 8 2 8}$ & & \\
SP & 0,086 & 0,419 & 0,437 & 0,475 & 0,597 & 0,574 & $\mathbf{0 , 8 2 6}$ & \\
TK & 0,244 & 0,382 & 0,679 & 0,445 & 0,848 & 0,561 & 0,500 & $\mathbf{0 , 8 6 7}$ \\
\hline
\end{tabular}

To test this requirement, the AVE of each construct should be higher than the highest squared correlation with any other construct (Hair et al., 2014). Table II shows that the values of AVE of each construct represented by bold numbers is higher than the highest squared correlation with any other construct as recommended by Hair et al. (2014), 
therefore, all constructs are valid measured based on the Fornell-Larcker criterion.

Discriminant validity was also measured by using heterotrait-monotrait (HTMT) with the threshold values of all items below the threshold point of 0.85 (Henseler et al.,
2015). Table III shows that HTMT values of all items are below the maximum point of 0.85 , therefore, this model is valid based on discriminant validity (HTMT).

Table III. Values of heterotrait-monotrait (HTMT)

\begin{tabular}{ccccccc}
\hline & CP1 & CP2 & IS & MS & SI & SP \\
\hline CP1 & & & & & & \\
CP2 & 0,739 & & & & & \\
IS & 0,385 & 0,487 & & & & \\
MS & 0,194 & 0,392 & 0,617 & & & \\
SI & 0,411 & 0,626 & 0,756 & 0,393 & & \\
SP & 0,114 & 0,506 & 0,487 & 0,512 & 0,643 & \\
TK & 0,270 & 0,431 & 0,750 & 0,466 & 0,607 & 0,540 \\
\hline
\end{tabular}

\subsection{Hypothesis Test}

Table IV presents the results of path coefficient test for the overall sample to examine hypotheses $\mathrm{H}_{1}, \mathrm{H}_{2}, \mathrm{H}_{3}, \mathrm{H}_{4}$ and $\mathrm{H}_{5}$ using SMART-PLS 3.0. Accordingly, the relationship between purchasing skills (PS) and corporate performance (CP), the $\mathrm{T}$ value (1.527) and $\mathrm{P}$ value (0.127), in which the $\mathrm{T}$ value is below the minimum threshold value of 1.96 , and the $\mathrm{P}$ value is higher than the maximum allowable value of 0.05 (Table IV) as recommended by Hair et al.(2014) and Hair et al. (2017). Therefore, hypothesis one $\left(\mathrm{H}_{1}\right)$ is rejected.

Table IV. Direct effects of relationship between variables

\begin{tabular}{lcccccc}
\hline & $\begin{array}{c}\text { Original } \\
\text { Sample } \\
(\mathrm{O})\end{array}$ & $\begin{array}{c}\text { Sample } \\
\text { Mean } \\
(\mathrm{M})\end{array}$ & $\begin{array}{c}\text { Standard } \\
\text { Deviation } \\
(\text { STDEV })\end{array}$ & $\begin{array}{c}\text { T Statistics } \\
(|\mathrm{O} / \mathrm{STDEV}|)\end{array}$ & P Values & Hypothesis \\
\hline PS -> CP & 0,283 & 0,352 & 0,185 & 1,527 & $\mathbf{0 , 1 2 7}$ & Rejected \\
PS -> SP & 0,597 & 0,626 & 0,071 & 8,402 & $\mathbf{0 , 0 0 0}$ & Supported \\
PS -> SI & 0,689 & 0,714 & 0,054 & 12,855 & $\mathbf{0 , 0 0 0}$ & Supported \\
SP -> CP & 0,074 & 0,089 & 0,108 & 0,688 & $\mathbf{0 , 4 9 2}$ & Rejected \\
SI -> CP & 0,397 & 0,366 & 0,183 & 2,171 & $\mathbf{0 , 0 3 0}$ & Supported \\
\hline
\end{tabular}

The relationship between purchasing skills (PS) and strategic purchasing (SP), using the $\mathrm{T}$ value (8.402) and $\mathrm{P}$ value (0.000) is shown below (Table IV). This shows that the $\mathrm{T}$ value beyond the minimum threshold value of 1.96 and the $P$ value below the maximum threshold value of 0.05 , means that purchasing skills (PS) has a positive and significant effect on strategic purchasing (SP). Therefore, hypothesis two $\left(\mathrm{H}_{2}\right)$ is supported. The result also indicates that the $\mathrm{T}$ value (12.855) and $\mathrm{P}$ value (0.000) of the relationship between purchasing skills (PS) and supplier integration (SI) has a positive and significant effect. Therefore, hypothesis three $\left(\mathrm{H}_{3}\right)$ is supported.
Table IV also indicates the $T$ value (0.688) and $P$ value (0.492) of the relationship between strategic purchasing (SP) and corporate performance (CP), which means both variables have a positive and significant effect. Therefore, hypothesis four $\left(\mathrm{H}_{4}\right)$ is not supported. In regard to the relationship between supplier integration (SI) and corporate performance (CP), the $\mathrm{T}$ value (2.771) and $\mathrm{P}$ value (0.030), means that supplier integration (SI) positively and significantly impacts on corporate performance (CP). Therefore, Hypothesis five $\left(\mathrm{H}_{5}\right)$ is supported.

Table $\mathrm{V}$ presents the results of the specific indirect effect test using bootstrapping SMART-PLS 3.0 for testing hypothesis $\mathrm{H}_{6}$ and $\mathrm{H}_{7}$. The result indicates that $T$ value 
(0.618) and $\mathrm{P}$ value (0.537) for mediation effect of strategic purchasing (SP) on the relationship between strategic purchasing (SP) and corporate performance has an insignificant effect.

Table V. Specific Indirect Effects (mediation effects)

\begin{tabular}{lcccccc}
\hline & $\begin{array}{c}\text { Original } \\
\text { Sample } \\
(\mathbf{O})\end{array}$ & $\begin{array}{c}\text { Sample } \\
\text { Mean } \\
(\mathbf{M})\end{array}$ & $\begin{array}{c}\text { Standard } \\
\text { Deviation } \\
(\text { STDEV })\end{array}$ & $\begin{array}{c}\text { T Statistics } \\
(|\mathbf{O S T D E V}|)\end{array}$ & P Values & Hypothesis \\
\hline PS -> SP -> CP & 0,044 & 0,057 & 0,072 & 0,618 & 0,537 & Rejected \\
PS -> SI -> CP & 0,274 & 0,259 & 0,128 & 2,132 & 0,033 & Supported \\
\hline
\end{tabular}

Therefore, Hypothesis six $\left(\mathrm{H}_{6}\right)$ is not supported. Conversely, the supplier integration (SI) fully mediates the relationship between purchasing skills (PS) and corporate performance (CP). This can be seen from the $\mathrm{T}$ value (2.132) and $\mathrm{P}$ value (0.033) according to the threshold values recommended by Hair et al. (2014) and Hair et al. (2017).

\section{Discussion}

One objective of this research is to test the influence of purchasing skills on corporate performance. The results show that purchasing skills had no significant influence on corporate performance. This is partly due to many restaurants being categorized as micro and small enterprises (MSEs) which have limited knowledge and skills in this area. Conversely, adequate knowledge and skills lead to enhanced corporate competitive advantages and secure sustainable corporate performance in recent dynamic industrial competitive environment (Barney, 1991, Gabrielsson et al., 2016; Saldanha, 2019). The result of this research is in line with the resource-based theory which states that corporates with better resources and capabilities have better competitive advantages and performance compared to those with limited resources and capabilities (Barney, 1991). Restaurants in this study having limited technical knowledge, interpersonal and managerial skills to undertake purchasing processes and functions, may have contributed to an insignificant effect on corporate performance. In addition, Karttunen (2018) stated that communication, technical and managerial skills as part of purchasing skills enable restaurants to ensure their purchasing efficiency. However, the result of this study is asymmetrical and relates to the previous studies from Carr and Smeltzer (2000), Schütz et al. (2019), and Cho et al. (2019) which revealed that purchasing skills, as reflected by technical knowledge, interpersonal, and managerial skills, have significant effects on corporate performance. The different results of empirical studies may be partly due to different sample sizes, different industry types, sizes, and environments (Saldanha el al., 2019) and heterogeneous resources and capabilities, face different strengths and weaknesses leading to different performances (Chun, 2016).
The second objective of this research is to test the influence of purchasing skills on strategic purchasing. The results show that purchasing skills have positive and significant effect on strategic purchasing. This means that technical knowledge, interpersonal skills and managerial skills make significant contributions to purchasing functions, and therefore, purchasing plans need to be regularly aligned with strategic plans, and have purchasing of items and quantities of materials/services included in strategic plans, along with the types of relationships with suppliers. Specific purchasing strategies need be developed in order to support corporate strategy, and formal business-planning processes. Good purchasing skills help corporates to develop better purchasing strategies. The results of this study also confirmed the findings of Cho et al. (2019) that interpersonal and managerial skills have a positive and significant effect on strategic purchasing. Therefore, interpersonal skills such as maintaining good relationships with suppliers, communication skills, good listening, and the ability to solve conflict, make significant contributions to enhanced strategic purchasing.

The third objective of this research is to test the mediation effect of strategic purchasing on the relationship between purchasing skills and corporate performance. The results revealed that strategic purchasing plays an insignificant role to in enhancing the relationship between purchasing skills and corporate performance. This is because most restaurants are categorized as micro and small enterprises (MSEs) (Cho et al., 2019), which have limited resources and capabilities to: (1) develop good purchasing strategy, (2) tend to use interpersonal skills in establishing collaborative work with suppliers, aiming to get good, cheap, quick, and continuous materials, (3) have poor strategic plan, limited managerial skills, and poor purchasing execution based on the plan, (4) mix corporate and family incomes and expenditures, and (5) poor report writing based on good corporate management (Hamzani and Achmad, 2016; Mandhachitara and Allapach, 2017; Xiang et al., 2019). The results of the study confirm the findings of Carr and Smeltzer (2000) that strategic purchasing had no significant effect on the relationship between purchasing skills and corporate performance in the context of SME restaurants. This also 
confirms that strategic purchasing has no significant effect on SME corporate performance, which in line with the limited resources and capabilities of the restaurants to develop good strategic purchasing, leads to poor purchasing and corporate performance. In this situation, corporates try to develop institutional collaboration to enhance competitive position, and ultimately enhance financial and nonfinancial performance (Lo et al., 2018; Chen, Tang and Jia, 2019; Cho et al., 2019).

This research also found that supplier integration has a significant effect on the relationship between purchasing skills and corporate performance. This means that collaborative work through supplier integration between buyers and suppliers enhances the relation between corporate's technical knowledge, interpersonal skills and managerial skills, and leads to improved ROI, ROA, net profit, total income, market share, sales volume and customer satisfaction. Through supplier integration, restaurants such as MSEs can join their resources, such as technical knowledge, managerial and interpersonal skills, to share production schedules, human resource capacity, inventory, planning, and product demand forecasts in order to secure sustainable financial and nonfinancial performance (Abrahamsen and Håkansson, 2015). Supplier integration can help corporates to obtain cheap supplies, shorten time delivery, and increase quality of products (Fliess and Becker, 2006). This leads to enhanced purchasing knowledge and skills to undertake purchasing functions, ultimately enhancing corporate performance (Chen, Tang and Jia, 2019). In the restaurant industry context, supplier integration can provide flexibility to respond to quick-changing customer demands, which help enhance competitiveness and menu diversification (Cho et al., 2019), leading to enhanced corporate performance (He et al., 2014; Nakos, Dimitratos and Elbanna, 2019).

\section{Conclusions and Implications}

Purchasing skills, strategic purchasing, and supplier integration are determinant factors that influence purchasing performance and overall corporate performance. Numerous empirical studies have recently utilized the mentioned variables in order to enhance corporate performance in competitive industry environments. The ultimate objectives of these studies are joint efforts to develop appropriate strategies in order to help corporates in obtaining cheap, quality, quick and continuous supply of products, aiming to reach cost efficiency, affordable prices, extend better market share and achieve high corporate performance compared to their rivals. To this end, corporates are willing to share their resources (technical knowledge, analytical, interpersonal and managerial skills) to develop strategic purchasing and supplier integration in order to improve purchasing performance, leading to achievement of high corporate performance.
The results of this study show that from direct effects, purchasing skills have positive but no significant impact on corporate performance. This insignificant effect could have occurred due to the limited knowledge and skills held by restaurants in the study which were generally characterized as micro and small enterprises (MSEs). As noted by several authors, MSEs are generally managed by the company owners, and utilize family as staff with limited professional knowledge and skills, poor financial management, and limited financial accessibility (Cho et al., 2019). Accordingly, MSEs have limited resources and capabilities to develop good and fit corporate strategies in order to retain high competitive advantages and secure sustainable performance. That is why it is not surprising to find that strategic purchasing has no significant effect on their corporate performance. Conversely, purchasing skills has a positive and significant effect on strategic purchasing and supplier integration. In addition, strategic purchasing has a positive but not significant effect on corporate performance, while supplier integration has a positive and significant effect on corporate performance.

The results of this study also show that based on the indirect effect test, strategic purchasing has no significant effect on the relationship between purchasing skills and corporate performance, while supplier integration fully mediates the relationship between purchasing skills and corporate performance.

From a theoretical perspective, this study contributes to extend the existing literature on purchasing skills, strategic purchasing, supplier integration and corporate performance in the restaurant industry by using combined strategic purchasing and supplier integration as mediation variables in an integrative model for enhancing the relationship between purchasing skills and corporate performance. This approach differs from previous studies, although it found heterogeneous results. Supplier integration positively and significantly influences the relationship between purchasing skills and corporate performance, while strategic purchasing is insignificant. Another theoretical contribution is that this study uses combined financial (i.e. ROI, ROA, net profit, and total income) and nonfinancial (i.e. market share, sale volume, customer satisfaction) indicators to measure corporate performance which had limited adoption by the previous studies, particularly in the restaurant sector. From a practical perspective, this study contributes evidence for managers and restaurant owners to consider supplier integration as an important factor to enhance financial and nonfinancial performance within the existing restaurants' technical knowledge, interpersonal and managerial skills. Sharing knowledge, skills, needs, products, and supply processes as mutual resources and capabilities between restaurants and suppliers in purchasing processes will enable restaurants to get quick, cheap, continuous supplies and 
quality products, leading to cost savings, enhanced purchasing performance and overall corporate performance.

\section{Limitation and Future Research}

This research has numerous limitations. First, this study only used questionnaires for data collection which rely entirely on the response of restaurant managers and owners, who may misrepresent data in order to protect their reputation and image. Therefore, for future research, we recommend to also unseen-depth interviews, focus group discussions and direct observation to validate responses from restaurant managers and owners to minimize the data bias. Second, this research was only carried out in the restaurant industry which may be difficult to generalize to other types of industries. Therefore, future research needs to be undertaken in other types of industries such as the construction industry, banking, commercial industries, and the manufacturing industry in Timor-Leste and other countries to allow better generalization across industries. Third, this study found that purchasing skills had an insignificant effect on corporate financial and nonfinancial performances, therefore, the authors used strategic purchasing and supplier integration as mediation factors to enhance corporate performance within the existing corporate's technical knowledge, interpersonal and managerial skills. For future research, we recommend to use a differentiation of strategy, such as cost leadership strategy, perceived innovation, entrepreneurship orientation and market orientation as mediating factors to enhance the relationship between purchasing skills and corporate performance. Fourth, this research is firstly carried out in Timor-Leste with cross-sectional data. For future research, we recommend to undertake longitudinal data in order to get better observation and conclusion for better generalization.

\section{Ackowledgements}

The authors would like to thank Dr. Estanislau de Sousa Saldanha for useful statistical suggestions and preliminary article content review. We would also like to thank restaurant managers, owners and students of the Department of Hotel Management at DIT who helped to carry out the data collection processes.

\section{References}

Abd Razak, N., Ab Rahman, Z. and Borhan, H. (2016) 'Modeling firm resources -enterprise risk management relationships: An empirical finding using PLS-SEM', World Journal of Entrepreneurship, Management and Sustainable Development, 12(1), pp. 35-49.

Abrahamsen, M. H. and Håkansson, H. (2015) 'Resource heterogeneity and its effects on interaction and integration in customer-supplier relationships', IMP Journal, 9(1), pp. 5-25.
Ahola, T. (2008). Purchasing strategies and value creation in industrial turnkey projects. International Journal of Project Management, 26, 87-94.

Al-Surmi, A., Cao, G. and Duan, Y. (2019) 'The impact of aligning business, IT, and marketing strategies on firm performance', Industrial Marketing Management, xxx, pp. xxx-xxx.

Andrei, A. G. et al. (2017) 'Word-of-mouth generation and brand communication strategy', Industrial Management \& Data Systems, 117(3), pp. 478-495.

Ateş, M. A., van Raaij, E. M. and Wynstra, F. (2018) 'The impact of purchasing strategy structure (mis)fit on purchasing cost and innovation performance', Journal of Purchasing and Supply Management, 24, pp. 68-82. doi: 10.1016/j.pursup.2017.05.002.

Barney, J. (1991) 'Firm Resources and Sustained Competitive Advantage', Journal of Management, pp. 99-120.

Carr, A. S. and Pearson, J. N. (2002) 'The impact of purchasing and supplier involvement on strategic purchasing and its impact on firm's performance', International Journal of Operations and Production Management, 22(9), pp. 1032-1053.

Carr, A. S. and Smeltzer, L. R. (2000) 'An Empirical Study of the Relationships among Purchasing Skills and Strategic Purchasing, Financial Performance, and Supplier Responsiveness', Journal of Supply Chain Management, 36(2), pp. 40-54.

Cepeda-Carrion, G., Cegarra-Navarro, J. G. and Cillo, V. (2019) 'Tips to use partial least squares structural equation modelling (PLS-SEM) in knowledge management', Journal of Knowledge Management, 23(1), pp. 67-89. doi: 10.1108/JKM-05-2018-0322.

Chen, L., Tang, O. and Jia, F. (2019) 'The moderating role of supplier involvement in achieving sustainability', Journal of Cleaner Production, 235, pp. 245-258.

Cho, M., Bonn, M. A., Giunipero, L., \& Divers, J. (2019). 'Restaurant purchasing skills and the impacts upon strategic purchasing and performance: The roles of supplier integration', International Journal of Hospitality Management, 78, pp. 293-303.

Cho, M., Bonn, M. A. and Terrell, B. B. (2019) 'Interaction effects between contract specificity, competence trust and goodwill trust upon supplier opportunism and relational stability: A focus upon restaurant performance', International Journal of Contemporary Hospitality Management, 31(3), pp. 1505-1524. doi: 10.1108/IJCHM-01-2018-0091.

Chun, D. (2016) 'Exploring connections: aspiration levels, culture and the resource based view', Journal of Strategy and Management, 9(2), pp. 202-215.

Danese, P. (2013) 'Supplier integration and company performance: A configurational view', Omega (United Kingdom), 41(6), pp. 1029-1041.

Feisel, E., Hartmann, E. and Schober, H. (2008) Purchasing skills - 
Developing the purchasing professional of the future. Wiesbaden, Germany.

Feyissa, T. T., Sharma, R. R. K. and Lai, K. K. (2019) 'The impact of the core company's strategy on the dimensions of supply chain integration', International Journal of Logistics Management, 30(1), pp. 231-260.

Fliess, S. and Becker, U. (2006) 'Supplier integration - Controlling of co-development processes', Industrial Marketing Management, 35(1), pp. 28-44.

Flynn, B. B., Huo, B. and Zhao, X. (2010) 'The impact of supply chain integration on performance: A contingency and configuration approach', IJournal of Operations Management, 28(1), pp. 58-71.

Foerstl, K. Evi Hartmann Finn Wynstra Roger Moseet. (2013) Kai Foerstl r, (2013)," "Cross-functional integration and functional coordination in purchasing and supply management: Antecedents and effects on purchasing and firm performance', International Journal of Operations and Production Management, 33(6), pp. 689721.

Gabrielsson, M., Seppäläb, T., \& Gabrielsson, P. (2016). Realizing a hybrid competitive strategy and achieving superior financial performance while internationalizing in the high-technology market. Industrial Marketing Management, 54, 141-153.

González-Rodríguez, M. R. Jiménez-Caballero, J. L., MartínSamper, R. C., Köseoglu, M. A. and Okumus, F (2018) 'Revisiting the link between business strategy and performance: Evidence from hotels', International Journal of Hospitality Management, 72(November 2017), pp. 21-31

Gunawan, H., Sinaga, B. L. and WP, S. P. (2019) 'Assessment of the Readiness of Micro, Small and Medium Enterprises in Using EMoney Using the Unified Theory of Acceptance and Use of Technology (UTAUT) Method', ScienceDirect Procedia Computer Science 161, 161, pp. 316-323.

Von Haartman, R. and Bengtsson, L. (2015) 'The impact of global purchasing and supplier integration on product innovation', International Journal of Operations and Production Management, 35(9), pp. 1295-1311.

Hair, J. Hollingsworth, C. L., Randolph, A. B., and Chong, A. Y. L. (2017) 'An updated and expanded assessment of PLS-SEM in information systems research', Industrial Management \& Data Systems, 117(3), pp. 442-458.

Hair, J.F. Sarstedt, M., Hopkins, L., and Kuppelwieser, V.G. (2014) 'Partial least squares structural equation modeling (PLS-SEM)', European Business Review, 26(2), pp. 106-121.

Hair, J.F. Hair, J. F., Hult, G.T.M., Ringle, C. M. and Sarstedt, M. (2014) Partial Least Squares Structural Equation Modeling (PlsSem). London: SAGE Publication LTD
Hair, J. F. et al. (2018) 'When to use and how to report the results of PLS-SEM', European Business Review, 31(1), pp. 2-24.

Hamzani, U. and Achmad, D. (2016) 'The Performance of Micro, Small and Medium Enterprises (MSMEs): Indigenous Ethnic Versus Non-Indigenous Ethnic', Procedia - Social and Behavioral Sciences, 219, pp. 265-271.

He, Y. Lai, K. K., Sun, H. and Chen, Y.(2014) 'The impact of supplier integration on customer integration and new product performance: The mediating role of manufacturing flexibility under trust theory', International Journal of Production Economics, 147(PART B), pp. 260-270.

Henseler, J., Ringle, C. M. and Sarstedt, M. (2015) 'A new criterion for assessing discriminant validity in variance-based structural equation modeling', Journal of the Academy of Marketing Science, 43(1), pp. 115-135.

Hilman, H. and Kaliappen, N. (2015) 'Innovation strategies and performance: are they truly linked?', World Journal of Entrepreneurship, Management and Sustainable Development, 11(1), pp. 48-63.

Huang, M. and Huang, H. (2019) 'How transaction-specific investments influence firm performance in buyer-supplier relationships: The mediating role of supply chain

Huo, B., Han, Z., Zhao, X., Zhou, H., Wood, C. H. and Zhai, X. (2013) 'The impact of institutional pressures on supplier integration and financial performance: Evidence from China', International Journal of Production Economics, 146(1), pp. 82-94

Jia, F., Lamming, R., Sartor, M., Orzes, G.and Nassimbeni, G. (2014) 'Global purchasing strategy and International Purchasing Offices: Evidence from case studies', Intenational Journal of Production Economics, 154(2014), pp. 284-298.

Karttunen, E. (2018) 'Purchasing and supply management skills revisited: an extensive literature review', Benchmarking, 25(9), pp. 3906-3934.

Kleinschmidt, E. J., De Brentani, U. and Salomo, S. (2007) 'Performance of global new product development programs: A resource-based view', Journal of Product Innovation Management, 24(5), pp. 419-441.

Lawson, B. Cousins, P., Handfield, R. and Petersen, K. J. (2009) 'Strategic purchasing, supply management practices and buyer performance improvement: An empirical study of UK manufacturing organisations', International Journal of Production Research, 47(10), pp. 2649-2667

Lee, Y., Kim, S., Seo, M. and Hight, S. K.(2015) 'Market orientation and business performance : Evidence from franchising industry', International Journal of Hospitality Management. Elsevier Ltd, 44, pp. 28-37.

Li, W. Y., Chow, P. S., Choi, T. M. and Chan, H. L. (2016) 'Supplier integration, green sustainability programs, and financial 
performance of fashion enterprises under global financial crisis', Journal of Cleaner Production, 135.

Lo, S. M., Zhang, S., Wang, Z. and Zhao, X. (2018) 'The impact of relationship quality and supplier development on green supply chain integration: A mediation and moderation analysis', Journal of Cleaner Production, 202, pp. 524-535

Lockström, M. and Lei, L. (2013) 'Antecedents to supplier integration in China: A partial least squares analysis', International Journal of Production Economics, 141(1), pp. 295-306.

Mandhachitara, R. and Allapach, S. (2017) 'Small business performance in Thailand: key success factors', Journal of Research in Marketing and Entrepreneurship, 19(2), pp. 161-181.

Nakos, G., Dimitratos, P. and Elbanna, S. (2019) 'The mediating role of alliances in the international market orientation-performance relationship of smes', International Business Review, 28(3), pp. 603-612.

Narasimhan, R. and Das, A. (2001) 'The impact of purchasing integration and practices on manufacturing performance', Journal of Operations Management, 19(5), pp. 593-609.

Saldanha, E. D. S. et al. (2018) 'The Role of Business Strategy in Mediating the Relationship Between Industrial Competition and Performances : A Study in the Higher Education Industry in TimorLeste', European Journal of Business and Management, 10(8), pp. $152-172$.

Saldanha, E. de S., Rahyuda, I. K., Yasa, Ni Nyoman Kerti, et al. (2019) 'Industrial Competition, Hybrid Strategy and Industrial Performance: Study in Higher Education in Timor-Leste', Journal of Engineering and Applied Science, 14(8), pp. 2456-2464.

Saldanha, E. de S., Rahyuda, I. K., Yasa, Ny Nyoaman Kerti, et al. (2019b) Persaingan Industri, Strategi Bisnis, Kinerja Industri. Denpasar: Udayana University Press.

Saldanha, E. de S. (2019). The Mediation Effects of Business Strategy on the Relations between Industrial Competition and Performance. Timor-Leste Journal of Business and Management, $1(1), 1-11$.

Salehzadeh, R. et al. (2017) 'The impact of internal marketing and market orientation on performance: an empirical study in restaurant industry', Measuring Business Excellence, 21(4), pp. 273-290

Schütz, K., Kässer, M., Blome, C. and Foerstl, K.(2019) 'How to achieve cost savings and strategic performance in purchasing simultaneously: A knowledge-based view', Journal of Purchasing and Supply Management, (April), p. 100534

Seifzadeh, P. and Rowe, W. G. (2019) 'The role of corporate controls and business-level strategy in business unit performance', Journal of Strategy and Management.

Thrulogachantar, P. and Zailani, S. (2011) 'The influence of purchasing strategies on manufacturing performance: An empirical study in Malaysia', Journal of Manufacturing Technology
Management, 22(5), pp. 641-663.

Wang, Zhining et al. (2016) 'The impact of intellectual capital knowledge management strategy fit on firm performance', Management Decision, 54(8), pp. 1861-1885.

Wang, Z., Huo, B., Qi, Y. and Zhao, X. (2016) 'A resource-based view on enablers of supplier integration: Evidence from China', Industrial Management and Data Systems, 116(3), pp. 416-444.

Xiang, D., Chen, J., Tripe, D. and Zhang, N. (2019) 'Family firms, sustainable innovation and financing cost: Evidence from Chinese hi-tech small and medium-sized enterprises', Technological Forecasting and Social Change, 144(March 2018), pp. 499-511.

Yang, Y. S., Kull, T. J., Nahm, A.Y. and Li, B. (2017) 'Attitudes toward supplier integration: the USA vs China', International Journal of Operations and Production Management, 37(8), pp. 1094-1116.

Yoon, J. and Moon, J. (2019) 'The moderating effect of buyer purchasing strategy on the relationship between supplier transaction-specific investment and supplier firm performance', Journal of Business Research, 99, pp. 516-523

\section{APPENDIX A. DATA COLLECTION INSTRUMENTS}

\section{PURCHASING SKILLS (PS)}

1.1. Technical knowledge (TK)

TK1: I am very knowledgeable about products in our market TK2: I am very knowledgeable about product price levels in our market

TK3: I am very knowledgeable about the major suppliers of our products

TK4: I am familiar with quality requirements of our products

TK5: I have a good understanding of every product that should be purchased

TK6: I fully understand the role of purchasing in our business

TK7: I am very knowledgeable about our marketing programs

TK8: I am very knowledgeable about financial management

\subsection{Interpersonal skills (IS)}

IS1: I work well with our suppliers

IS2: I have good communication skills with our suppliers

IS3: I am a good listener with our suppliers

IS4: I am able to maintain a positive relationship with our suppliers IS5: I can handle any conflicts with our suppliers IS6: I am persuasive with our suppliers

\subsection{Managerial Skills (SM)}

MS1: I develop and implement purchasing plans

MS2: I am able to re-organize our work schedule for effective purchasing

MS3: I am able to adjust our business activities to meet purchasing plans

MS4: I develop purchasing objectives and strategies that meet our company goals

MS5: I am able to control purchasing plans for new product/ service development

MS6: I am a purchasing leader in our restaurant industry

MS7: I communicate well with our suppliers about products needed 
by our employees Factor

\section{STRATEGIC PURCHASINING (SP)}

SP1: Our purchasing function has a formal strategic plan

SP2: Our strategic plan is reviewed and adjusted to match changes in our restaurant strategic plans on a regular basis

SP3: Our strategic plan includes both the items and quantities of materials or services to be purchased

SP4: Our strategic plan includes various types of relationships to be established with suppliers

SP5: Specific purchasing strategies have been developed to support our restaurant's strategies

SP6: Our restaurant has a formal business-planning process

\section{SUPPLIER INTEGRATION (SI)}

SI1: Our major supplier shares their production schedule with us SI2: Our major supplier shares their production capacity with us

SI3: Our major supplier shares available inventory with us

SI4: We share our production plan with our major suppliers

SI5: We share our demand forecasts with our major suppliers

\section{CORPORATE PERFORMANCE (CP)}

CP1: Financial Performance

CP11: Our return on investment (ROI) increase in the last three years

CP12: Our return on assets (ROA) increase in the last three years

CP13: Our net profit increase in the last three years.

CP14: Our total incomes increase in the last three years

CP2: Non-Financial Performance

CP21: Our market share increase in the last three years

CP22: Our sale volume increase in the last three years.

CP23: Our customer's satisfaction on our products increase in the last three years. 